\title{
REPRODUCING SACRED LIKENESS IN EARLY MODERN ITALY
}

This essay explores the concept of "sacred likeness" in relation to copies of a potent miraculous image in Florence, Italy, known as the Santissima Annunziata (Plate I), made by the painter Alessandro Allori, in the late sixteenth century. An investigation of Allori's copies of the SS. Annunziata touches upon many of the salient themes addressed in this conference volume, such as the authenticity, authority, and agency ascribed to the faithful copy; the relativity and fluidity of the concept of fidelity in reproduction; the impact of new technologies and mechanical forms of reproduction; the political investment in, and control over, reproducing cultural heritage; and the ambiguous figure of the image-maker in the discourse on faithful copying in the visual arts.

Marion Heisterberg, Susanne Müller-Bechtel, and Antonia Putzger, have referred to the recent "renaissance of the copy" - the new interest in replicas and replication. They note, however, that the emphasis in this recent scholarship is on the difference between the copies and the so-called "originals", and on the generation of "something new". ${ }^{1}$ The subject of "sacred likeness" has been addressed by a number of scholars in this recent "renaissance of the copy", with sophisticated paradigms offered for rethinking replication. ${ }^{2}$ Directly relevant to the topic of this essay, Jane Garnett and Gervase Rosser highlight the significant role played by reproduction in devotion to miracle-working images. The copies of miraculous images, however, according to Garnett and Rosser, are not precise. They exhibit "a lack of concern with very close formal correspondence". ${ }^{3}$ The copies are approximate and transformed through replication. This deviation from the formal appearance of the original is characterized positively as a generative process of dissemination, where the image cult either resists the control of church authorities or moves out

1 Heisterberg, Müller-Bechtel, and Putzger, in their statement accompanying the call for papers for the conference Nichts Neues Schaffen/Creating Nothing New held in Hannover, June 26-28, 2014. Cf. also the introductory remarks of Heisterberg/Putzger/Müller-Bechtel in this volume.

2 Maniura/Sheperd 2006; Wood 2008; Nagel/Wood 2010; Garnett/Rosser 2013, Chapter 5: The Power of the Infinite Copy, 191-219; Kubersky-Piredda 2014.

3 Garnett/Rosser 2013, 213. 
of institutional control into popular hands. The mobile mutable copy represents a productive appropriation, a translation, a re-contextualization of the original miraculous image. When the precise copy does appear in Garnett and Rosser's account, it is usually associated with reactionary attempts by church authorities or the patrons or custodians of a miraculous image to control a cult and promote an official authorized reproduction of the image.

Allori's copies of the SS. Annunziata, too, have been investigated in this recent examination of reproduction. Susanne Kubersky-Piredda approaches Allori's copies from the perspective of Medicean cultural politics. She considers the critical importance in the reproductive enterprise of Allori's authorship, of questions of authenticity, of the precise format of the copies, and - particularly useful for our purposes - of the resemblance between Allori's copies and the miracle-working painting. ${ }^{4}$ I will make use of her thoughtful investigation, while considering more extensively the cultic context of reproduction and directing my inquiry more pointedly toward the matter of precision in copying. In this way we will be able to test the case of Allori's copies of the SS. Annunziata in relation to the concept of the "faithful" copy, in light of this recent scholarship on replication and "sacred likeness". I will begin by reflecting briefly on the conceptualization and the semantics of the particular type of copying that I am considering here.

Miraculous images, in early modern Catholic religious culture, were sacred representations - usually panel paintings, frescoes, and sculptures of the Virgin Mary and the Crucified Christ - that were considered to be particularly active sites of potent sacred intercession. ${ }^{5}$ People turned to these images in times of great need and left candles and other ex-voto offerings of thanks when their prayers were answered. While miracleworking images were frequently copied, the nature of the relationship between the "original" cult images and the copies made after them proves to be somewhat slippery. This was because miraculous images, on account of their very nature as sacralized matter, were difficult to delineate, delimit, and translate in the reproductive process. This will become apparent in introducing the particular case of the miracle-working SS. Annunziata.

The SS. Annunziata fresco (Plate I), enshrined in a tabernacle, is located on the inner façade wall of a church in Florence, named after the miraculous image, belonging to the Servite monastic order. From a modern-day art historical perspective, this painting of the Annunciation can be dated to circa 1340 and attributed to a Florentine master working under the influence of Giotto, Taddeo Gaddi, and Bernardo Daddi. ${ }^{6}$ The painting

4 Kubersky-Piredda 2014.

5 Two recent publications on miraculous images, with bibliography, are Garnett/Rosser 2013 and Holmes 2013.

6 On the early history of the SS. Annunziata miraculous image, see Holmes 2004a, 97-122. See also Husabø Oen 2011, for a thoughtful reflection on the fifteenth-century developments of the cult, in dialogue with Nagel/Wood 2010. 
1 Luca Ferrini, God Painting the SS. Annunziata, woodcut from Corona di sessantatre miracoli della Nunziata di Firenze (1593), folio X

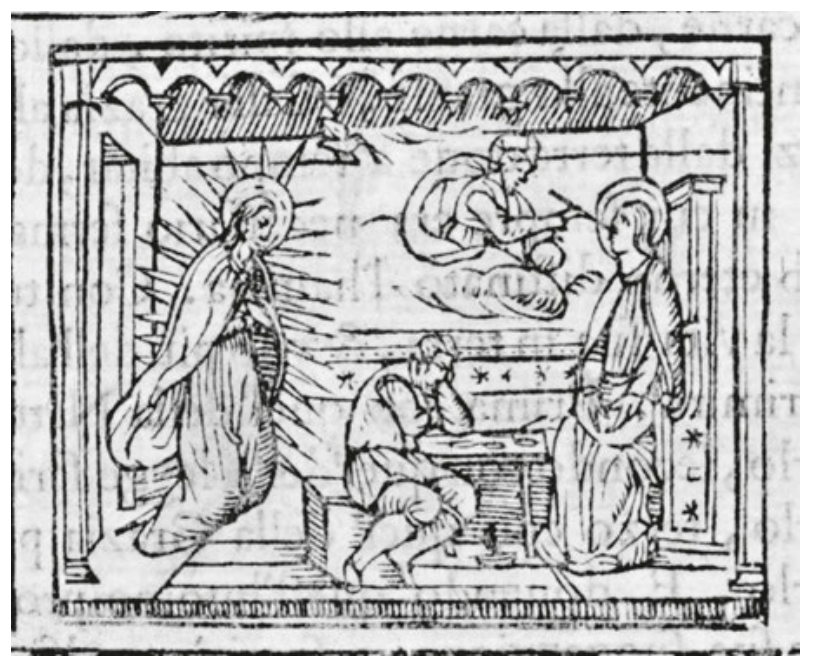

appears to have become active as a highly venerated image by 1360 , when devotion intensified and the image was considered to be the site of potent sacred intercession, with special privileges extended by the papacy to the related cult. Over two hundred years later, in Alessandro Allori's day, in the late sixteenth century, the SS. Annunziata had become the most celebrated miracle-working image in the city of Florence and the dukedom of Tuscany, ruled by the Medici family. ${ }^{7}$ The SS. Annunziata was at the pinnacle of a fluid hierarchy of wonder-working images, each with its respective community of devotees and domain of influence in the city and beyond. There was a legend now associated with the miraculous image, claiming that the Annunciation had been painted in the year 1252 by a pious local artist named Bartolomeo. ${ }^{8}$ Supposedly this artist had had difficulty fashioning the face of the Virgin to his satisfaction and the painting was only completed after an angel intervened and painted the Virgin's face. This legend of an image made

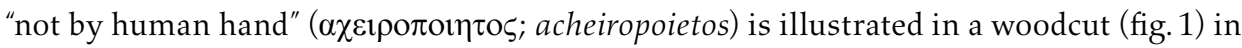
a late sixteenth century collection of miracle stories related to the cult. ${ }^{9}$ In the woodcut, instead of an angel, God himself is shown wielding the paintbrush.

The SS. Annunziata, as a miraculous image, and a miraculous image made "not by human hand", was thus extraordinary. The true qualities of the sacred image - its materiality and figuration, particularly the "Holy Head" (Santa Testa) - were ultimately elusive, incomprehensible, and irreducible. Conceptually, the Virgin's face was an authorized "true likeness" (vera icona), generated by holy means, similar to the icons of the

7 On the cult of the SS. Annunziata in the sixteenth century, see Fantoni 1989 and 1994; Iarocci 2015.

8 On the evolution of this legend, see Holmes 2004a, 97-104.

9 Ferrini 1593, fol. 10. 
Virgin said to have been painted by St. Luke in the early Christian period. ${ }^{10}$ These most sacred portraits were never fully accessible to the human senses. They were enshrined within lavish tabernacles, hidden behind veils, and rarely seen; their infrequent unveilings were accompanied by liturgical ceremony and procession, and were witnessed by large assemblies of people with heightened emotions and expectations. ${ }^{11}$ These most celebrated sacred images were also thought to be difficult to perceive and comprehend by means of the human corporeal senses and cognition. ${ }^{12}$ There is an anecdote told about Michelangelo being shown the SS. Annunziata in the company of the Florentine Duke. When asked to give his opinion of the miraculous image, Michelangelo remained silent and immobile, either "in a stupor brought upon the senses by the divine face or with his spirit overcome by fear of the divine beauty". ${ }^{13}$ Scholars have argued that these elusive highly venerated images were substantiated and experienced through their copies. Christopher Wood and Alexander Nagel have even asserted that all sacred images were, in a sense, "replicas" positioned within chains of replicated types that linked backward in time to putative authoritative early Christian "true likenesses" of Christ, the Virgin, and saints. ${ }^{14}$ The efficacy of highly venerated images was dependent on visual access to copies and derivative images.

The challenge, then, will be to understand how a copy of the SS. Annunziata might be considered "faithful" or "true", and how this veracity was evaluated in the period when the original image itself was considered to be so unknowable. Of particular interest is how the rhetoric of "truthfulness" functioned in the context of reproduction. We will be interested, too, in the technical means of producing "truthfulness", and what visual form this rhetoric of "truthfulness" took in the copies made by Allori.

There is another factor to consider that had an impact on the "prototype-copy" affiliation in the reproduction of miraculous images. A certain ambiguity could exist in the relationship between the sacred image and the transcendent sacred being represented in the image. Conventional Christian image theory made a distinction between the material image in the earthly domain-made of wood, stone, plaster, paint-and the transcendent sacred being in heaven. Devotion directed to the image was said to proceed to the

10 On Madonna images said to have been painted by St. Luke, see Bacci 1998.

11 On the enshrinement and veiling/unveiling of miraculous images, see Holmes 2013, Chapter 7.

12 In the early-thirteenth century, Gervase of Tilbury, in his Otia imperialia, claimed that looking directly at the Veronica could be fatal; Gerald of Wales, in his Speculum Ecclesiae, observed that an unnamed pope had been blinded by the Veronica (Noreen 2006, 5, with the Latin texts on page 9 , notes 41 and 42).

13 Bocchi 1592, 82. In response to the Duke's question "Ditemi un poco, che vi pare di questa Imagine?" Bocchi writes, "In questo, o fosse lo stupore che nella vista del divin volto gli avea i sensi occupati, o soprapreso l'animo da timore di divina bellezza, altrimenti non fece motto il Buonarroto".

14 Wood 2008; Nagel/Wood 2005, 403-432; Nagel/Wood 2010. On the relationship of the reproduction of sacred images to medieval image theory, see Kessler 2000, 64-87. 
sacred being in heaven. ${ }^{15}$ This distinction broke down with miraculous images, where the sacred being was understood to operate "in and through" the material effigy, and to be "present" in the sanctuary environment, and responsive to the prayers that were addressed to the image. ${ }^{16}$ As the number of miracle-working images increased in Italy during the late medieval and early modern periods, the individual images acquired identities that were linked to the sites where they were located and where they performed. These distinct identities could also be based on characteristics particular to the image or to the related cult. Images were known by these toponyms and distinguishing characteristics: the "Madonna of Impruneta", the "Madonna del Sangue", the "Crucifix of San Giovanni". In Allori's day, the SS. Annunziata was called "La Nunziata di Firenze" - or "The Virgin Annunciate of Florence". The ambiguity was that the sacred being, too, was referred to by the same title. "La Nunziata di Firenze" referred to the Virgin herself, who operated "in and through" her special image in Florence, as a preferred site. Prayers were addressed to "La Nunziata" and she appeared to people in visions. This naming practice was reminiscent of that in classical antique Greco-Roman sanctuaries, where cults were associated with particular places and with the competency of the god operating at the site - "Athena Parthenos". In the case of the Christian image cults, the image and the sacred intercessor could be treated by devotees as if coextensive. The Virgin Mary was present and active "in and through" her image. The image, in turn, was an active site of the sacred presence, virtue, and earthly intercession of the Virgin Mary. This interesting elision between sacred being and sacred image is evident in the woodcut illustrations in Luca Ferrini's late sixteenth century printed miracle book from the SS. Annunziata. In these miracle stories, "La Nunziata di Firenze" appears in the narratives, responding to prayers and assisting people in times of need. In the vast majority of the woodcuts accompanying the miracle stories, "La Nunziata di Firenze" is shown in the heavens, in a schematic rendering of the full composition of the miracle working Annunciation image, surrounded by rays. In a few instances, however, she is represented as a haloed female figure interacting in the terrestrial domain, actively aiding a person in distress. ${ }^{17}$ There

15 St. Basil, in a widely-known text included in the Acts of the Second Council of Nicaea, had written: "For the honor shown to an icon applies directly to its living model and he who venerates the icon, therefore, venerates in it the person of the one so depicted." ("Imaginis enim honor ad primitivum transit; \& qui adorat imaginem adorat in ea depicti subsistentiam.") (Mansi 1767, vol. 13, $373 \mathrm{E}-380 \mathrm{~A})$.

16 On medieval Christian image theory, see Kitzinger 1954; Belting 1994; Schönborn 1994; Maniura 2011. For theoretical perspectives on miraculous images, see Garnett/Rosser 2013, Chapter 1; Holmes 2013, 6-9, and Chapters 5 and 6.

17 Ferrini 1593. The Virgin is shown in the guise of the miraculous Annunciation image in 55 of the 63 miracle stories (see, for example, Holmes 2011, 458, fig. 19). The Virgin appears as a single figure interacting with the human protagonist in just two of the woodcuts (miracle numbers 5 [13r] and $7[19 \mathrm{v}])$. In five of the woodcuts, the Virgin/image is absent, with just rays shown in the heavens, while in the foundation miracle she is represented in the fresco, with God miraculously painting her face (1r). 


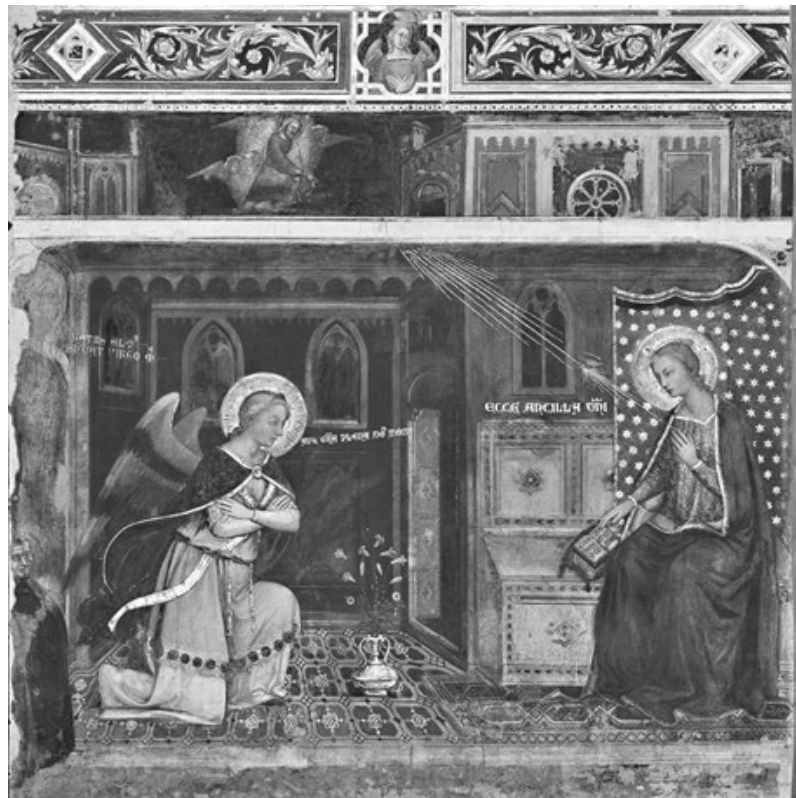

2 Copy of the SS. Annunziata, 1371, fresco, Florence, San Marco

were implications for copies of the miracle-working image. The copies, too, functioned as privileged sites for accessing the intercession of "La Nunziata di Firenze" - whatever the level of resemblance. It was enough for a copy to be recognized as linked in some way with the original image - by means of resemblance, through an inscribed title or prayer that named "La Nunziata di Firenze", by having touched the original miraculous image, or by other means. ${ }^{18}$ As Jane Garnett and Gervase Rosser note:

the pilgrim [...] makes a point to visit the shrine site of the original manifestation of a particular wonder-working Madonna. Yet that very Madonna is understood to be equally present in every image proclaimed to be her copy, however approximate the formal resemblance may appear, and however modest or mass-produced the object may be. ${ }^{19}$

The efficacy of copies could also lead to their becoming miracle-working images in their own right, as Garnett and Rosser have demonstrated in their investigation of Ligurian

18 The copy of the SS. Annunziata made by Allori and gifted by the Medici to King Philip II of Spain bore the inscription: "ADMIRABILEM IMAGINEM DIVAE ANUNCIATAE DE FLORENTIA, ALEXANDER ALLORIUS, CIVIS FLORENTINUS, ANGELI BRONZINI ALUMNUS, MANDATOMAGNI DUCIS AETRURIAE EFFINGEBAT A.S.N. MDLXXXIIII" (Kubersky-Piredda 2014, 211, note 40). An example of a printed woodcut copy being rubbed against a miraculous image is given by Robert Maniura, in reference to the cult of the Madonna delle Carceri in Prato (Maniura 2004, 86-93).

19 Garnett/Rosser 2013, 193. 
3 Alessandro Allori, Copy of the SS. Annunziata, 1579-1580, oil on canvas, storage, Milan, Cathedral

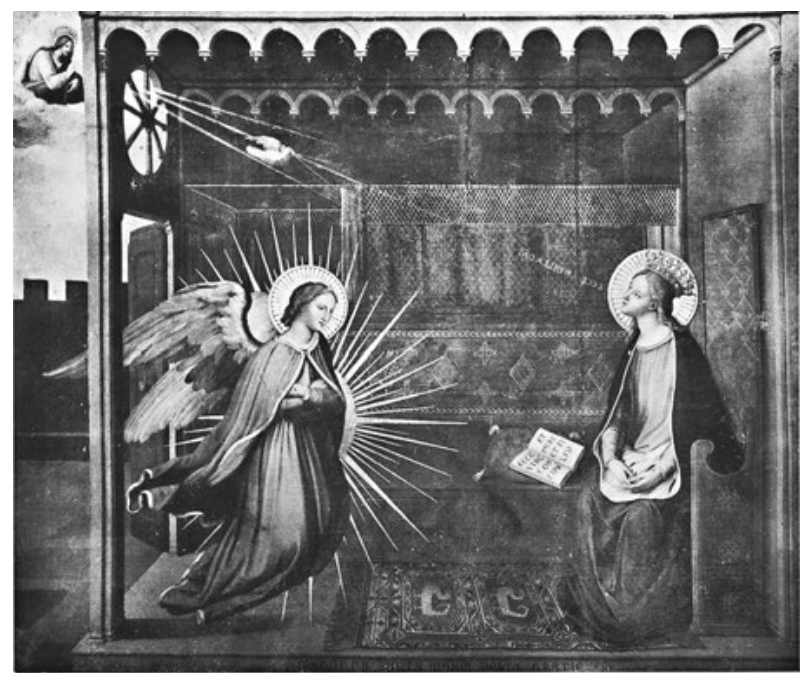

image cults. ${ }^{20}$ In Florence, a copy of the SS. Annunziata in the church of San Marco (fig. 2) was considered to be miracle-working. ${ }^{21}$

Let us turn, then, to the copying enterprise of Alessandro Allori. The first of his copies of the SS. Annunziata (fig. 3) dates to 1579-80 and can be constructively compared to the earlier reproduction from San Marco, Florence, dating to 1371 (fig. 2). The San Marco copy is characteristic of the reproductions of the SS. Annunziata made shortly after the miraculous image became active. ${ }^{22}$ In the early copies, resemblance between the original miraculous Annunciation and the derivative paintings was established through the use of a basic recognizable compositional armature and a variety of visual cues. ${ }^{23}$ The bedroom setting is reproduced, with the angel positioned at the left, and the Virgin seated to the right on a bench in a shallow foreground space. Any number of the following visual cues was enough to secure a relationship to the original fresco: the distinctive arm positions of the Virgin and Gabriel, the upward tilt of the Virgin's head, the pattern of the oriental carpet, the intarsia decoration on the back of the bench, the curve of the arm of the Virgin's seat, the exposed ermine lining of the Virgin's robe, the mesh and folds of the bed curtain at the back of the scene and the repetitive arches in the architectural molding above, the open book on the pillow inscribed with Isaiah's prophecy, the

20 Garnett/Rosser 2013, 204-206.

21 The frescoed copy of the SS. Annunziata at San Marco (1371) in Florence developed a cult by at least 1540 (see Holmes 2013, 156).

22 On trecento copies, see Holmes 2004a, 104-110; Renner 1996, 103-108; Miller/Taylor-Mitchell 2009. A number of the papers addressed reproduction in the conference Das Gnadenbild der Santissima Annunziata in Florenz (Kunsthistorisches Institut in Florence, April 23-24, 2009).

23 Holmes 2004a, 104-110. 
backward lettering "ECCE ANCILLA DOMINI" articulating the Virgin's message of acceptance to God, and the golden rays issuing forth from God and passing through a cartwheel-shaped window. The upward tilt of the Virgin's head and the three-quarter view of her face gradually took on greater importance in the copies in the early fifteenth century, when the legend began to circulate that the Virgin's face had been painted by an angel. In these copies, combinations of these visual references to the miraculous fresco were apparently sufficient to link the surrogate images to the physical site in Florence and to the enshrined sacred image "in and through" which the Virgin and God operated. These copies would probably have been commissioned according to the contract convention "in the manner and in the form" (in modo et forma) of the SS. Annunziata fresco. ${ }^{24}$ These early copies were "faithful" and "true" in accordance both with the reproductive practices characteristic of the period and with the cultural understandings about how the efficacy of a miraculous image could be transmitted through secondary images. "Faithful" and "true", in regard to a copy, are thus best understood as relative terms.

The reproduction of the SS. Annunziata became much less frequent after the middle of the fifteenth century, when the Medici family became the principle patrons of the image cult. The miraculous image was rarely shown to the public, and could go years without being unveiled. ${ }^{25}$ The Medici appear to have actively discouraged the reproduction of the fresco, with one occasion when they punished the head of the monastic Servite Order when he produced an unauthorized copy for the Medici's political adversary, the Holy Roman Emperor. ${ }^{26}$ Medici control over access to the image increased significantly after 1532, when the family became the hereditary rulers of the Florentine state. The Medici soon had complete control over access to the SS. Annunziata, taking possession [1558] of the two keys that unlocked the shutters covering the image and determining the occasions when it would be shown to the public, to members of the Florentine elite, and to visiting diplomats and dignitaries. ${ }^{27}$

The Medici changed their strategies quite abruptly, however, at the end of the sixteenth century. They began to promote the production of copies and the wide dissemination of these reproductions. ${ }^{28}$ This practice started with the copy commissioned by the Medici from Allori in 1579 (fig. 3). Seemingly, the Medici were spurred on by the promotion of prominent image cults following the Council of Trent, during the period of Catholic reform. They were also encouraged by other ruling families in Europe that had established close relationships with image cults - like the Savoy family in Turin, which

24 On the contract clause in modo et forma, see O'Malley 2005, 222.

25 Holmes 2013, 225.

26 Holmes 2013, 81.

27 Holmes 2013, 225; Iarocci, 2015.

28 This change in policy regarding copying the SS. Annunziata by the Medici is very nicely documented by Kubersky-Piredda 2014. On the Medici relationship to the cult, see Fantoni 1989 and 1994; Iarocci 2015. 
owned the Turin Shroud. ${ }^{29}$ Another important development was the manner in which new reproductive technologies were put to service in the copying enterprise, particularly print and the use of cartoons to generate painted replicas. The fifteenth and sixteenth centuries had witnessed radical changes in the culture of copying and reproduction, across a variety of artisanal and artistic practices. ${ }^{30}$ Reproduction played a role at both the low and high end of production. Sculptors and painters created a veritable Madonna industry, using molds to cast devotional images in terracotta, gesso, and papier-mâché. Painters used pounced drawings known as cartoons (spolvere) to transfer designs and to generate multiples. Reproduction played a role, too, in canon formation at this time. Print-makers and publishers produced engravings of celebrated compositions, for example by Raphael, Michelangelo, and Titian. ${ }^{31}$ These compositions, too, were translated into other media. A high-end ecclesiastical textile, for example, reproduced Verrocchio's Doubting Thomas from one of the exterior niches at Orsanmichele in Florence, in a design that itself was generated in multiples on the weaver's loom. ${ }^{32}$

In the case of the renewed practice of reproducing the SS. Annunziata, beginning in the late sixteenth century, there was a marked increase in the degree of similitude in evidence, along with new strategies for guaranteeing the "truthfulness" of the copy to the original. ${ }^{33}$ Furthermore, the SS. Annunziata began to circulate widely in print at the very same time that the Medici began to authorize painted reproductions. The Servites generated an engraved copy in 1586, executed by Cesare Capranica, which became the basis for subsequent printed copies. The miraculous image was also illustrated in miracle books produced in the late sixteenth and early seventeenth centuries. ${ }^{34}$

Allori's first copy (fig. 3) was a commission from Duke Francesco I de' Medici for Cardinal Carlo Borromeo, Archbishop of Milan. ${ }^{35}$ The commission corresponded with the visit to Florence of the Cardinals Carlo Borromeo and Gabriele Paleotti, two of the most

29 On the Turin Shroud, see Morello/Wolf 2000, 278-301; Scott 2003, Casper 2013 and Casper (forthcoming).

30 On transformations in reproductive practices and technologies in fifteenth century Italy, see Holmes 2003 and Holmes 2004b. See Loh 2004 and Loh 2007 for an innovative theorization of later early modern repetition.

31 Landau and Parshall 1994, 162-168, on the category of the "reproductive print"; Pon 2004.

32 In the Museo del Tessuto di Prato, reproduced in Degl'Innocenti 2000, 52.

33 Kubersky-Piredda demonstrates the emphasis on similitude in the copies commissioned from Allori. She speculates that cartoons were used to produce these copies (Kubersky-Piredda 2014, 213). For the evidence of Allori's use of cartoons, see note 54 below.

34 Eckhard Leuschner discovered the 1586 engraving authorized by the Servites, discussed in his paper "Die Verkündigung der Verkündigung: Zur internationalen Verbreitung des Gnadenbildes von SS. Annunziata über die Reproduktionsgraphik" in the conference Das Gnadenbild der Santissima Annunziata in Florenz (Kunsthistorisches Institut in Florence, April 23-24, 2009). For printed illustrations of the SS. Annunziata in a miracle book see Ferrini 1593.

35 The primary sources for Allori's copy of the SS. Annunziata for Carlo Borromeo are: Allori 1908, 12 (entry 1580, April/May); AFS, MDP 254, folio 67 (letter from Duke Francesco I de' Medici to Carlo Borromeo, 1580, July 11; Borghini 1584, 628; Bocchi 1592, 88 f.; Baldinucci 1728, vol. 3, 522; In the secondary literature, see Lecchini Giovannoni 1991, 54 and 251 f.; Kubersky-Piredda 2014, 207-209. 
important reformers of the Counter-Reformation Catholic church. The Cardinals were treated to a rare unveiling of the miraculous image during their visit to Florence. Borromeo then requested a "ritratto" of the miraculous image. ${ }^{36}$ Ritratto, in the early modern period, could mean "portrait" or a tracing - literally a "redrawing" - of an image. ${ }^{37}$ According to one source, Borromeo requested that his copy be "as similar as possible" (quanto piú simile si potesse) - so there was clearly a rhetoric operating in the copying enterprise at this time that placed a value on similitude and that linked the "truthfulness" of the copy to an assessment of similitude. ${ }^{38}$ The involvement in this case of "faithful copying" of both the architect of Catholic reform, Borromeo, and the ruling Medici would seem to confirm Jane Garnett and Gervase Rosser's observation that greater fidelity is often found in copies of miraculous images that were authorized by religious or political authorities seeking to regulate the cult. Here, access to the original was critical, and the Medici had the keys. ${ }^{39}$

Allori, around the same time that he was commissioned to paint the copy, was also given the task of cleaning the miraculous image, which had become obscured by dust and dirt. ${ }^{40}$ This cleaning is interesting, particularly given that art historians maintain that one of the distinguishing characteristics of highly venerated images in the early modern period is their archaic look - their darkening over time and outmoded style, which endowed them with an aura of authority and difference from normative contemporary devotional images. ${ }^{41}$ It would appear, however, that a certain degree of clarity and legibility of the miraculous image was deemed desirable for its display to the cardinals and also for its reproduction.

The cleansing of the image involved touching the sacralized matter of the fresco, coming into intimate contact with the "Holy Head" of the Virgin. There is a description of Allori's cleaning of the fresco where the procedure is treated like a ritual, devotional act. The painter is said to have confessed and taken communion before beginning his

36 Ritratto is the term found in all of the contemporary primary sources for Allori's copy for Borromeo. Allori, in his Ricordi, for example, wrote: "Dal Ser[...]mo Gran Duca Francesco scudi dodici di moneta, cioè lire ottantaquatro, tanti sono per a buon conto della tela per il Cardinal Buonromeo del ritratto della Nuntiata di Firenze" (1580, between April 2 and May 7), Allori 1908, 12.

37 On the term retrahere - to trace or redraw - in the context of Renaissance reproduction, see Holmes $2004 b, 48 \mathrm{f}$.

38 Francesco Bocchi describes how Borromeo "[...] dopo la visita della Santissima Nunziata, à qui di verderla fu conceduto con suo agio come grazia singulare domandò al Gran Duca Francesco, che in un quadro à suo nome qui in Fiorenza ella fosse ritratta quanta piu simile si potesse" (Bocchi 1592, 88).

39 Kubersky-Piredda provides conclusive evidence of this exclusive control over the image on the part of the Medici in a letter written in 1588 by a member of the Spanish court to Duke Ferdinando I: "Todos me an dicho que no oy pintor que lo sepa haazer come conviene si no uno que era del Grand Duque que esta en el cielo y no hazia ninguna obra sin lincencia de Su Ser.d y que tanbien era menester perdirsela para copiar la imagen porque en su proprio poder estavan las llavesa" (ASF, MDP, 5079, ins. 3, f. 528, in Kubersky-Piredda 2014, 211 and 212, note 42).

40 This cleaning is described by Bocchi 1592, 72 f.; see the discussion in Kubersky-Piredda $2014,212$.

41 Belting 1994, 15 f., 471, 484 f.; Nagel/Wood 2010, 71-83; Holmes 2013, 157-163 and 202-205. 
work. ${ }^{42}$ Allori's assistant, who was kneeling on the altar before the image, became overwhelmed and swooned, but was miraculously not injured when he fell to the ground. ${ }^{43}$ Kubersky-Piredda has likened this account of the cleaning to the originary legend of the cult, where the painter Bartolomeo, positioned before the unfinished fresco, was overwhelmed by the task of painting the face of the Virgin.

In preparing to make his copy, Allori traced over the principle figures and generated a set of cartoons. ${ }^{44}$ The act of tracing, as noted above, put Allori in intimate contact with the fresco - with the sense of "touch" understood in the period as a critical means of transmitting sacred charisma. ${ }^{45}$ The cartoons, in turn, distilled a "delineation" of the sacred figures on scale with the original design. In line with Christian image theory, these lineaments of the Virgin corresponded to her "figura" - or her outwardly visible shape including the "true likeness" of her face generated by divine agency. The scale outline of the Virgin's face registered in the cartoon endowed the reproductions made with the cartoon with the same kind of authenticity found in printed images of sacred relics that were said to be made according to the same measurements as the originals - such as in hand-colored prints depicting the relic of the Holy Lance that pierced the side of Christ. ${ }^{46}$ The cartoon-generated replication of the miraculous image also resonated metaphorically with the very subject depicted in the SS. Annunziata - the Incarnation - the Word made flesh in divine reproduction.

The cartoon-method of composing the figures is evident in Allori's "faithful" copy. There is precision in reproducing the scale and the body positions of the sacred figures. Allori's copy includes all of the distinctive features in the Annunciation composition that had long been associated with copies, enumerated above. Many of these features, however, are approximate in their measurement and detail in the copy - like the open book on the pillow and the oriental carpet - and they were not made with the use of cartoons. Some license is taken by Allori in elaborating the spatial setting, with accomplished perspective used to construct the Virgin's bedroom and greater atmosphere in the exterior scene at the left, where God is shown. The Angel Gabriel now appears to hover more convincingly in the air.

42 Bocchi 1592, 72: "Alessandro Allori [...] prima che si mettesse all'opera, si confessò, et appresso si comunicò."

43 Bocchi 1592, 73: "[U]n suo huomo, [...] in su l'altare si era messo ginocchione, et presso da maraviglia hora una cosa hora un altra attentamente contemplava. [...] [C]adde a terra dell'altare, che molto è alto, et, come piacque a Dio, da questa Vergine miracolosa aiutato, non si fece nella sua vita alcune male."

44 In the letter written by Francesco I de' Medici to Carlo Borromeo, the Duke notes that the copy is the same size as the original ("dclla mcdcsima grandezza"); ASF, MDP, 254, folio 67, quoted in Kubersky-Piredda 2014, 208, note 26. Similar language is found in Borghini and Baldinucci, as noted by Kubersky-Piredda 2014, 213 and note 45. Evidence for Allori's use of cartoons in generating copies of the SS. Annunziata comes from a later documented instance, when Allori created a fresco copy for the nunnery of San Jacopo in Bagno a Ripoli in 1589, discussed below.

45 On touch, see Holmes 2013, 194-202; Garnett/Rosser 2013, $174 \mathrm{f}$.

46 Wood 2008, 153-155. 
This "faithful copy" was sent to Milan along with a letter from the Medici Duke indicating the extreme rarity of the gift. The letter rhetorically insisted: "never in any other time, has a copy been made". ${ }^{47}$ We hear that Borromeo received the copy with pleasure and installed it in the cathedral in Milan, where it eventually became a cult image in its own right. In one contemporary account, Francesco Bocchi recounts that Borromeo, while initially satisfied with his copy, nonetheless, tested the degree of "likeness" between the original and his copy the next time that he was in Florence and was permitted to see the SS. Annunziata unveiled. He commented, "The portrait of La Nunziata that was sent to Milan did not resemble this miraculous image of the Madonna of Florence, nor did it conform with her rare beauty". ${ }^{48}$ In reply, he was told that human artistry was simply incapable of reaching such heights. ${ }^{49}$ Allori's "faithful copy" of the miraculous image, thus, in this narrative account, served the rhetorical purpose of asserting the primacy, authenticity, and authority of the original miracle-working image. The copy also demonstrated an incommensurability between the original and the copy, and reaffirmed the distinction between divine and human artifice. The "faithful copy" here is shadowed not only by the original, but also by the specter of the "unfaithful copy".

The cartoons remained in the possession of Allori. He went on to use the cartoons to produce multiple copies of the SS. Annunziata in a variety of formats - one assumes, with the permission of the Medici. Allori's account book has fortuitously survived from this period and it informs us that in two years alone, in 1582 and 1583, he painted five copies of the full composition, three sets of the heads of the Virgin and the Angel, seven isolated heads of the Virgin, and one head of just the angel. ${ }^{50}$ Some of these derivatives were on scale with the original, others reduced in size. Allori used canvas, panel, and copper as the support. In another very prestigious Medici commission, Allori painted for King Philip II of Spain a large head of the Virgin, and then, at the special request of the King, a scale version of the full composition, both on canvas. ${ }^{51}$ This cross-cultural implantation of the cult of the SS. Annunziata in Hapsburg Spain led to a number of com-

47 "[...] né mai più per alcuno tempo sc n'è cavata copia" (AFS, MDP, 254, folio 67, dated July 11, 1580), reproduced and discussed in Kubersky-Piredda, 207 f.; see also the discussion in Fantoni 1989, 791.

48 "....] disse, come il ritratto della Nunziata, che á Milano gli era stato mandato, non punto somigliava questa miracolosa Madonna di Fiorenza, ne à sua rara belezza punto era conforme", Bocchi 1592, 89.

49 "come ne di industria, ne di accuratezza ha mancato il pittore, perche il suo volere sia fornito; ma tenga per certo, come in darne si afattica chi con humano studio crede di arrivare à cosa tanto divina si come è questa. Perche ne il pittore con suo artifizio, ne la facoltà del dire con parole, ne l'huomo col pensiero tanto si innalza, che adegui l'alto valore di questa sacrata Vergine." Bocchi $1592,89$.

50 Allori 1908, 17-23; Lecchini Giovannoni 1991, 54, 61, 251 f., 256; figs. 172, 189, 190.

51 Allori 1908, 17-20. Kubersky-Piredda 2014, 209-211. Kubersky-Piredda notes how the initial gift of the Virgin's head alone was not well received and the Spanish King requested a version of the full image to scale, communicated in a diplomatic dispatch of 18 July, 1583: "facessi ritrarre la Nontiata nel medesimo modo che la sta in Fiorenza nella tavola [sic] propria dove è il ritratto suo." Kubersky-Piredda 2014, 209. 
4 Copy of the SS. Annunziata, designed by Alessandro Allori and woven by Gasparri di Bartolomeo Papini, 1593-1597, detail of a dalmatic, Rome, Vatican Museums

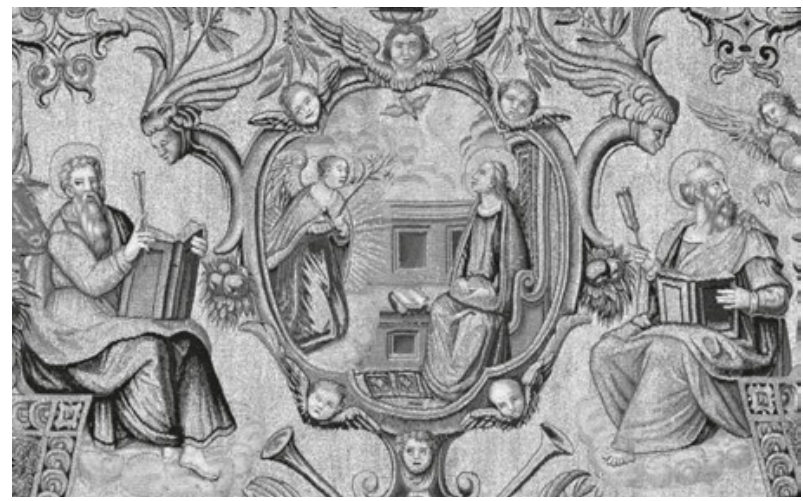

missions for copies from the Spanish nobility. ${ }^{52}$ In a later example of transmediation and reduction, Allori produced the design for a small Annunciation scene (fig. 4) on a dalmatic that was given, as part of a set of ecclesiastical vestments, as a gift from the Medici Duke to Pope Clement VIII for use in the Sistine chapel. ${ }^{53}$

There is a documented commission for a copy of the SS. Annunziata in Florence that illustrates the variety and range of choices available to clients when commissioning their copies. In 1589, the Abbess of the Dominican nunnery San Jacopo in Ripoli ordered a copy for the nun's inner church. The frescoed copy itself does not survive, but the nunnery's account book tells us that the abbess specifically referred to the cartoon in Allori's possession derived from the miraculous image. She also left open room for variation in the copy. The relevant entry in the nunnery's account book reads:

La Nuntiata will be painted in fresco, with the figure of the Madonna and the Angel; the excellent painter Messer Alessandro Allori [...] will paint it in his own hand and the Madonna will be made with the cartoon (spolverezzo) from the Annunciation here in Florence, which is so celebrated and invoked; the angel will be somewhat different from that one, primarily in the clothing. ${ }^{54}$

This interesting relationship between precise copying and variation, specified in the contract, is indicative of both the art market in the late sixteenth century and the culture of reproduction at the time. Clients commissioning works of art and purchasing serial

52 Kubersky-Piredda 2014, 210, note 38.

53 The commission originated with Duke Francesco I de' Medici and was concluded by Ferdinando I, with the dalmatic woven in Florence by Gasparri di Bartolomeo Papini, between 1593 and 1597. Cf. exh. cat. New York 1982, $77 \mathrm{f}$.

54 “Nel [...]anno 1589, dalla parte destra del [...] altare nella facciata della [...] chiesa di drento, [...] si fece dipignere la nuntiata a fresco, e la figura della madonna e dellangelo, la dipinse di sua propia mano leccellente pittore Messer Alessandro Allori, detto il Bronzino; e la madonna e fatta in su lo spolverezzo della nuntiata qui di Firenze, la quale etanto celebre e nominata, langelo e alquanto diverso da quello, e massimamente nel vestito [...]" (Archivio di Stato, Florence, San Jacopo di Ripoli, n. 22, unnumbered first page [verso]), published in part in Padoa Rizzo 1997, 165. 
products were used to making choices based on pre-existing models and specific needs. Artists, in turn, were accustomed to referencing pre-existing works of art, utilizing reproductive technology to facilitate production and to guarantee the fidelity of a copy, and to introduce variation, innovation, and visibly discernable autograph workmanship, in the form of signature styles and motifs. ${ }^{55}$

In the case of Allori, as Kubersky-Piredda has demonstrated, the very subject of the SS. Annunziata became linked with the artist and his workshop production and even became a motif associated with his signature style. ${ }^{56} \mathrm{His}$ paintings of the SS. Annunziata (fig. 3; Plates II, III) activated the powerful intercession associated with the cult, but could also have encouraged the viewer to locate and compare "faithful" copying in the paintings with the artful demonstration of the painterly hand of Allori. Allori could render a "true likeness" of the "Holy Head" of the Virgin, with the veracity of the copy guaranteed through the use of the cartoons derived from the tracing of the miraculous image. Certain pictorial features where called upon to communicate archaism associated with cult: the flat, static golden haloes of the figures and the schematic rays radiating from the angel. These features appear disjunctive and stylistically outmoded, reaffirming the link to the miraculous prototype, and the expectations of potent intercession guaranteed through this linkage. In this way, Allori could also call attention to his own artistry and the agency of his brushwork. He could use the aesthetic tools of his trade to create an analogous experience of awe and wonder. Allori could overwhelm the senses with his soft modeling (morbidezza) and his vibrant colors (colorito). Using the most modern and up-to-date pictorial techniques, he could suggest the extraordinary beauty of the Madonna, the splendid chromatic wings and levitation of Gabriel, and the miraculous appearance of divine and sacred presence in the earthly realm. Note, for example, the contrast between the way in which Allori claims authorship in a set of the heads of Gabriel (Plate II) and the Virgin (Plate III) that he also made for Carlo Borromeo. ${ }^{57}$ Both paintings are signed, but one in a much more obvious manner than the other. In the painting of the Virgin, Allori inscribes his name just below the lower triangle in the intarsia design of the bench: "Alessandro Bronzino Allori, Florentine citizen, painted [this]." The black lettering, however, is barely perceptible against the brown of the simulated wood and the geometric pattern picked out in gold. ${ }^{58}$ In this reproduction of the Virgin's "Holy Head", painted by an angel in the original fresco, Allori deemphasizes his role as the maker of the painting. In the companion piece (fig. 5), in contrast, Allori makes a bolder claim to have painted the head of the Angel Gabriel. He signs the painting with a

55 Holmes 2004b.

56 Kubersky-Piredda 2014, 211-215.

57 Lecchini Giovannoni 1991, 256.

58 Allori signed the painting of the Virgin "ALEX. BRONZINIUS ALORIUS CIV. FLO. PINGEBAT". He signed the painting of the Angel Gabriel "ALEXANDER BRONZINIUS ALLORIUS CIV. FLORENTINUS FAC." Cf. Lecchini Giovannoni 1991, 256; Kubersky-Piredda 2014, $211 \mathrm{f}$. 
5 Detail of Plate II, with signature of Alessandro Allori

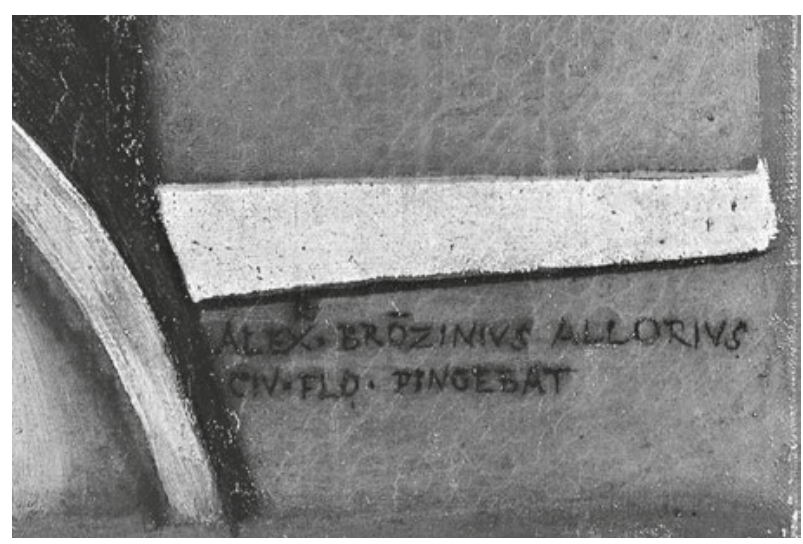

similar inscription, but with the lettering much more visible here, inscribed beneath a golden ray, against the light neutral ground. There may even be a subtle reference to the "painter's hand" here. The inscription is positioned right at the level of the hidden hands of Gabriel - a distinctive feature of the miraculous prototype. Could this be a subtle or even humorous way of declaring that this image - this elegant copy - was made "not by angelic hand" - but by the accomplished hand of the Florentine master? It is also possible that there is another order of personal investment indexed through the overt signature - a reference to a votive prayer or thanks by the painter himself, as Allori negotiated his own relationship with the sacred through this prestigious commission. ${ }^{59}$

Allori articulated his privileged relationship to the SS. Annunizata in his wider painting practice as well, consolidating his signature style. The head of the Virgin from the SS. Annunziata is cleverly integrated into paintings that otherwise have nothing in common with the SS. Annunziata composition, such as The Virgin and Child with St. Francis and St. Lucy (1583) in the National Collection in Wales. La Nunziata's face is playfully adapted for the figure of St. Catherine, instead, in Allori's Virgin and Child with SS. Catherine of Alexandria and Francis in the Cobb Collection. ${ }^{60}$ In these paintings, the gendered pictorial and religious values associated with the beauty, grace, mercy, and efficacious intercession of La Nunziata are re-contextualized in these new painterly performances.

I will conclude by restating some of the claims about "faithful" copying that I have made in this paper that can potentially be of use for our broader interrogation of this category of reproduction in this volume of conference papers. In Allori's reproductions of the SS. Annunziata, "faithful" and "true" copying operated on a number of different, but

59 I want to thank Antonia Putzger for this suggestion and for noting an analogy with the manner in which Michiel Coxcie signed his copy of the the Ghent Altarpiece.

60 I thank Bernice Iarocci for calling my attention to these paintings and their use of the Virgin's head from the SS. Annunziata. 
interrelated levels. There was a technical level, where tracing and pricked cartoons were used to transfer the design from the original to the derivative works, guaranteeing a certain degree of conformity. Allori had been given privileged access to the miracle-working fresco in order to make these cartoons and the cartoons themselves were generated through contact with the sacred image. Allori's cartoon-produced copies, in turn, became the source for new printed copies of the miraculous fresco, which had wide circulation throughout Europe. There was a discursive, rhetorical level, where Allori's paintings claimed to be "portraits" that could transmit something of the highly valued "true likeness" of "La Nunziata di Firenze" in the original fresco, made by divine means, activating the potent intercession of "La Nunziata". This rhetorical claim could be challenged in order to reaffirm the authority of the prototype, as we saw in the story about Cardinal Borromeo emphasizing the difference between the original and Allori's copy. But this rhetorical claim could also be creatively deployed to add value to the copy itself as a masterful recreation, and thereby turn into a rhetoric of characterization and distinction. ${ }^{61}$

A "faithful copy" is, ultimately, a relative term, with different criteria for establishing veracity in the prototype-copy relationship in different historical and cultural contexts. Notions about "faithfulness" or "truth" in copying are linked to reproductive technologies, to the ways in which images "performed", and to cultural conceptions about "resemblance". Furthermore, "fidelity" and "truth" in copying do not necessarily rely on visual resemblance. "Fidelity" and "truth" can be transmitted through other means - such as an inscription linking the copy to the prototype or by the knowledge that a reproductive print had been rubbed against the original miraculous image, by the effective substitution of a copy in a procession, or just by the general demonstration that the copy could trigger the same efficacy associated with the original. ${ }^{62}$ Another consideration is that the "faithful copy" can also have a binary dimension, where it is shadowed by its opposite, the "unfaithful copy". This binary relationship between the "faithful copy" and the "unfaithful copy", as conceptual poles, encourages comparison, judgment, and valuation. This comparison can be utilized to reassert the authority and uniqueness of the original prototype, as we saw in the case of Cardinal Borromeo and Allori's copy. But this comparison can also be deployed positively and constructively to assert different values and qualities associated with "truth" in copying and with "variation" in copying. The Dominican abbess, for instance, wanted the figure of Gabriel in the copy of the SS. Annunziata that she commissioned for her nunnery to be different from the angel in the original miracle-working fresco. And finally, "truth in copying" is a fluid, flexible term that can be integrated into a multi-faceted reproductive practice like that of Allori's, where it was mobilized in multiple contexts, in different ways, with different valuations, even within a single painting. The example of Allori suggests that "sacred likeness" linked to sacred

61 Kubersky-Piredda 2014, 211-215.

62 Nagel/Wood 2010; Bynum 2011, 37-123; Casper 213; Garnett/Rosser 2013, 191-220; Holmes 2013, 269-271 
presence, in and through devotional images, does not necessarily have to be set in opposition to "artistic agency", across a Medieval and early modern divide. The early modern copy could be a generative site to thematize both divine and human artifice, to consider the hand of an angel, and the hand of a skilled painter, and to explore the paradox of representation. The histories of sacred reproduction and of early modern imitation and emulation, do not have to be told in separate chapters.

Allori's practice ultimately affirms a claim made by Jane Garnett and Gervase Rosser about the reproduction of miraculous images. They assert that the copying of miraculous images

deconstructs the conventional view which holds the distinction between 'the original' and 'a copy' to be hierarchical [...]. The historical dynamic of an image cult shows the impossibility, in every case, of confining the picture in question to a unique instantiation and meaning [...] [T] he potentially infinite iterations of the Madonna's image refuse to be reduced to a simple message or to a differentiated hierarchy of authority. ${ }^{63}$

\section{Bibliography}

Allori, Alessandro: I ricordi [1579-1584], ed. by Igino B. Supino, Florence 1908.

Bacci, Michele: Il penello dell'Evangelista. Storia delle immagini sacre attribuite a San Luca, Pisa 1998.

Baldinucci, Filippo: Notizie de' professori del disegno da Cimabue in qua, 6 vols., Florence 1728.

Belting, Hans: Likeness and Presence. A History of the Image Before the Age of Art, Chicago 1994.

Borghini, Rafaello: Il Riposo, Florence 1584.

Bynum, Caroline Walker: Christian Materiality. An Essay on Religion in Late Medieval Europe, New York 2011.

Casper, Andrew: Display and Devotion. Exhibiting Icons and their Copies in Counter-Reformation Italy, in: Religion and the Senses in Early Modern Europe, ed. by Wietse de Boer and Christine Göttler, Leiden, 2013, 43-62.

Casper, Andrew: The Shroud of Turin as Art, Icon, and Relic in Early Modern Italy (forthcoming).

Degl'Innocenti, Daniela [et al.]: I tessuti della fede. Bordi figurati del XV e XVI secolo dalle collezioni del Museo del Tessuto di Prato, Prato 2000.

Exh. cat. The Vatican Collections. The Papacy and Art (New York, Metropolitan Museum of Art 1983), New York 1982.

Fantoni, Marcello: Il culto dell'Annunziata e la sacralità del potere mediceo, in: Archivo storico italiano, 147.1989 (542), 771-793.

Fantoni, Marcello: La corte del Granduca. Forma e simboli del potere mediceo fra Cinque e Seicento, Rome 1994.

Ferrini, Luca: Corona di sessanta tre miracoli della Nunziata di Firenze, Florence 1593.

Garnett, Jane / Rosser, Gervase: Spectacular Miracles. Transforming Images in Italy from the Renaissance to the Present, London 2013.

Holmes, Megan: Neri di Bicci and the Commodification of Artistic Values, in: The Art Market in Italy $\left(15^{\text {th }}-17^{\text {th }}\right.$ Centuries), ed. by Marcello Fantoni, Louisa Chevalier Matthew, and Sara Matthews-Grieco, Ferrara 2003, 213-223.

Holmes, Megan: The Elusive Origins of the Cult of the Annunziata in Florence, in: Thunø/Wolf (eds.) 2004, 97-122 [Holmes 2004a].

63 Garnett/Rosser 2013, 193. 
Holmes, Megan: Copying Practices and Marketing Strategies in a Fifteenth-Century Florentine Painter's Workshop, in: Italian Renaissance Cities. Artistic Exchange and Cultural Translation, ed. by Stephen Campbell and Steven Milner, Cambridge and New York 2004, 38-74 [Holmes 2004b]. Holmes, Megan: Miraculous Images in Renaissance Florence, in: Art History, 34.2011, 432-465. Holmes, Megan: The Miraculous Image in Renaissance Florence, New Haven and London 2013.

Husabø Oen, Maria: The Origins of a Miraculous Image: Notes on the Annunciation Fresco in SS. Annunziata in Florence, in: Konsthistorisk tidskrift/Journal of Art History, 80.2011 (1), 1-22.

Iarocci, Bernice: The Santissima Annunziata of Florence, Medici Portraits, and the Counter-Reformation in Italy, PhD dissertation, University of Toronto 2015.

Kessler, Herbert: Configuring the Invisible by Copying the Holy Face, in: idem: Spiritual Seeing. Picturing God's Invisibility in Medieval Art, Philadelphia 2000, 64-87.

Kitzinger, Ernst: The Cult of Images in the Age Before Iconoclasm, Dumbarton Oaks Papers, 8.1954, $83-150$.

Kubersky-Piredda, Susanne: “... Et sia ritratto nella forma medesima”. Das Florentiner Gnadenbild der SS. Annunziata und seine Repliken, in: Multiples in Pre-Modern Art, ed. by Walter Cupperi, Zurich 2014, 201-228.

Landau, David / Parshall, Peter: The Renaissance Print, 1470-1550, New Haven and London 1994.

Lecchini Giovannoni, Simona: Alessandro Allori, Turin, 1991.

Loh, Maria: New and Improved. Repetition as Originality in Italian Baroque Practice and Theory, in: The Art Bulletin, 86.2004, (3), 477-504.

Loh, Maria: Titian Remade. Repetition and the Transformation of Early Modern Italian Art, Los Angeles 2007.

Maniura, Robert: The Images and Miracles of Santa Maria delle Carceri, in: Thunø/Wolf (eds.) 2004, 81-96.

Maniura, Robert/Sheperd, Rupert: Presence. The Inherence of the Prototype Within Images and Other Objects, Aldershot 2006.

Maniura, Robert: Icon/Image, in: Material Religion. The Journal of Objects, Art and Belief, 7.2011 (1), $50-56$.

Mansi, Giovanni Domenico: Sanctorum conciliorum nova et amplissima collectio, 31 vols., Florence and Venice 1759-1798.

Miller, Julia / Taylor-Mitchell, Laurie: Humility and Piety. The Annunciation in the Church of Ognissanti in Florence, in: Studies in Iconography, 30.2009, 42-71.

Morello, Giovanni / Wolf, Gerhard: Il volto di Cristo, Milan 2000.

Nagel, Alexander/Wood, Christopher: Toward a New Model of Renaissance Anachronism, in: The Art Bulletin, 87.2005, 403-432.

Nagel, Alexander/Wood, Christopher: Anachronic Renaissance, New York 2010.

Noreen, Kirstin: Revealing the Sacred. The Icon of Christ in the Sancta Sanctorum, Rome, in: Word and Image, 22.2006, 1-10.

O'Malley, Michelle: The Business of Art. Contracts and Commissioning Practices in Renaissance Italy, New Haven and London 2005.

Pon, Lisa: Raphael, Dürer, and Marcantonio Raimondi. Copying and the Italian Renaissance Print, New Haven and London, 2004.

Padoa Rizzo, Anna: Il monastero di San Jacopo di Ripoli e il suo patrimonio artistico, in: Villa La Quiete. Il patrimonio artistico del conservatorio delle Montalve, ed. by Cristina De Benedictis, Florence 1997, 157-195.

Renner, Stefanie: Die Darstellung der Verkündigung an Maria in der florentinischen Malerei: Von Andrea Orcagna (1346) bis Lorenzo Monaco (1425), Bonn 1996.

Schönborn, Christoph: God's Human Face. The Christ Icon, San Francisco 1994.

Scott, John Beldon: Architecture for the Shroud: Relic and Ritual in Turin, Chicago 2003.

Thunø, Erik / Wolf, Gerhard (eds.): The Miraculous Image in the Late Middle Ages and Renaissance, Rome 2004.

Wood, Christopher: Forgery, Replica, Fiction. Temporalities of German Renaissance Art, Chicago 2008. 